\title{
Bevacizumab/Lomustine Regimen
}

National Cancer Institute

\section{Source}

National Cancer Institute. Bevacizumab/Lomustine Regimen. NCI Thesaurus. Code

C160526.

A regimen consisting of bevacizumab and lomustine that can be used for the treatment of glioblastoma (GBM). 